\title{
Otwarte formutowanie strategii z wykorzystaniem kolektywnej inteligencji przedsiębiorstwa
}

Prof. dr hab. Elżbieta Urbanowska-Sojkin

Uniwersytet Ekonomiczny w Poznaniu Instytut Zarządzania, Katedra Zarządzania Strategicznego

Dr Adam Weinert

Uniwersytet Ekonomiczny w Poznaniu Instytut Zarządzania, Katedra Zarządzania Strategicznego

\section{Wprowadzenie}

Warunki, w których funkcjonują współczesne przedsiębiorstwa, mają wpływ na działania podejmowane względem otoczenia oraz ich skuteczność. Zadaniem kierownictwa przedsiębiorstwa jest ustalenie i zapewnienie możliwości rozwojowych wynikających z potencjału zasobowego i cech przyszłego otoczenia. Zadania te realizowane są $\mathrm{w}$ trakcie formułowania strategii, a następnie jej wdrażania i realizacji. Efektem podejmowanych działań przedsiębiorstwa jest stopień dostosowania do zmieniających się warunków otoczenia. Na znaczeniu zyskują zatem te narzędzia, procesy, postawy, zachowania i podmioty, które mają w sobie potencjał w tym zakresie. Celem opracowania jest ustalenie ram koncepcyjnych otwartej strategii, wspartych na jej kolektywnym współtworzeniu oraz przedstawienie wstępnych, częściowych wyników badania.

Treść opracowania opiera się na założeniu, że przedsiębiorstwo nieustannie modyfikuje swoje zachowania na rynku jako skutek warunków w otoczeniu oraz wiedzy i uczenia się, a współtworzenie strategii warunkuje skuteczność i efektywność poprzez ograniczenie niepewności. Otwartość strategiczna jest konstruktem, który może być użytecznym narzędziem do badań empirycznych i wnioskowania o przyczynach. Opracowanie jest zatem bardziej teoretyzowaniem niż sprawdzaniem teorii, a zaprezentowane wyniki badania stanowią podstawę do dyskusji i ukierunkowania dalszych badań. Przedmiotem odniesienia jest inteligencja przedsiębiorstwa i interesariuszy (kolektywna inteligencja), ujmowana w kategoriach wymiernych 
lub quasi-wymiernych, której skutkiem jest wartość dodana z kontaktów, wymiany wiedzy, informacji i poglądów, a także kreatywność i innowacyjność oraz racjonalność metodyczna i rzeczowa zarządzania.

W rozdziale skupiono się na przedstawieniu działania polegającego na łączeniu i koordynowaniu formułowania i wdrażania strategii przez przedsiębiorstwo i inne zainteresowane podmioty, wykorzystującego ich inspiracje powodowane inteligencją zamiast podmiotowego zamknięcia (lock-in). Dla realizacji celu wykorzystano systematyczne, przedmiotowe badania literatury anglojęzycznej i niemieckojęzycznej (systematic literature review - SLR). Fundamentem dynamicznego współtworzenia strategii i jej implementacji, poprzez wykorzystanie kolektywnej inteligencji, są dotychczasowe i współczesne doświadczenia współpracy gospodarczej, oczekiwane korzyści kalkulacyjne i pozakalkulacyjne, przymusy administracyjne i instytucje formalne. W dalszej części opracowania wskazano użyteczność kolektywnej inteligencji w obszarze otwartości strategicznej, a w szczególności w procesie formułowania strategii przez przedsiębiorstwa w warunkach polskich ${ }^{1}$.

\section{Kolektywna inteligencja i zorganizowana kreatywność}

Historyczny nadruk problematyki kolektywnej inteligencji jest związany z procesem podejmowania decyzji innym niż indywidualny, niekiedy nazywanym - w zależności od uczestniczących w nim podmiotów i pełnionych ról - grupowym, zespołowym. Z założenia zdolność do najlepszego rozwiązania problemu w kolektywie jest wyższa niż wówczas, gdy tworzy je jednostka. Praktyka zarządzania potwierdza znaczenie indywidualnego lub zespołowego procesu podejmowania decyzji ${ }^{2}$, w mniejszym zakresie posługując się określeniem kolektywne. Jest to między innymi konsekwencja rozumienia natury przedsiębiorstwa, ról menedżerów oraz pracowników. Kluczowe znaczenie mają zatem relacje otoczenia z przedsiębiorstwem. Analiza tych relacji na osi czasu wskazuje na ich ewolucję pod wpływem dynamiki i złożoności otoczenia oraz na imperatyw dynamicznego dostosowywania się do niego, warunkujący trwałość przedsiębiorstwa na rynku. Fundamentalne wyzwania związane z bytem rynkowym i trwaniem na rynku dotyczą tworzenia

1 Ze względu na charakter rozdziału wyniki całego procesu postępowania badawczego zostaną opublikowane w innym opracowaniu. Obszerność podjętej problematyki przyczynita się do syntezy wyników systematycznego przeglądu literatury oraz badania w przedsiębiorstwach.

2 A.K. Koźmiński, W. Piotrowski, Zarzq̨dzanie. Teoria i praktyka, Wydawnictwo Naukowe PWN, Warszawa 2013. 
wartości dla klienta, ale także wartości dla właścicieli i innych interesariuszy. Warunkiem koniecznym, ale niewystarczającym do skutecznego działania przedsiębiorstwa jest podejmowanie problemów zarządzania strategicznego w szerszym kontekście, z uwzględnieniem innych podmiotów. Upoważnieniem do tego są relacje współpracy, współistnienia i działalności w strukturach gospodarczych, społecznych, administracyjnych o zasięgu krajowym i zagranicznym. Są one wyrazem zarówno legitymizacji poznawczej, pragmatycznej, jak i moralnej.

Udział kolektywu w zarządzaniu organizacjami dostrzeżono już dawno na gruncie nauk społecznych, a wsparciem w ogromnym zakresie okazały się możliwości tworzone przez technologie informacyjno-komunikacyjne (Information and Communication Technologies - ICT) - inspirujące, poprzez aplikacje i oprogramowanie IT, do rozważania kwestii związanych z wymianą danych, informacji i myśli oraz do wykorzystania zbiorowej inteligencji.

Levy uznaje zbiorową inteligencję za formę powszechnie rozproszonej inteligencji, stale ulepszanej, skoordynowanej w czasie rzeczywistym i widocznej w efektywnym wykorzystaniu umiejętności, gdzie każdy człowiek ma pewną wiedzę, ale żaden nie posiada całej wiedzy o wszystkim. Autor ten w opinii Jacobsena uważa projekt inteligencji zbiorowej za „projekt humanistyczny”, odgrywający istotną rolę w społeczeństwie obywatelskim, między innymi dzięki zwiększonemu dostępowi do wiedzy33. W sposób naturalny powstają pytania o elementy objęte mianem inteligencji - przedsiębiorstwa, kolektywnej i zbiorowej. Dla dalszych rozważań i ustaleń przyjęto, że inteligencja człowieka to umiejętności i zdolności zdobywania, rozumienia i wykorzystywania informacji i wiedzy w różnych sytuacjach, warunkowane inteligencją emocjonalną 4 .

Inteligencja ludzi w przedsiębiorstwie jest w nim inkorporowana i znajduje odzwierciedlenie w systemach, procesach, produktach, wiedzy, rutynach organizacyjnych, a także relacjach współdziałania. Retoryczne pozostają pytania, czy inteligencja ludzi w przedsiębiorstwie podlega reakcjom synergii, relacjom komplementarności, czy też substytucyjności. Wymienione rodzaje relacji intencjonalnie wskazują na pozytywne efekty łączenia indywidualnych, osobniczych pokładów wiedzy i zdolności jej wykorzystania do rozwiązywania problemów. W tym ujęciu inteligencja przedsiębiorstwa dotyczy kolektywnej zdolności do rozwoju jego kompetencji ${ }^{5}$. Nie oznacza to jednak zgodności co do natury owej inteligencji. Utożsamia się ją często z elementami tworzącymi jej strukturę, czyli z informacją,

3 A. Jacobsen, Intelligenz von Unternehmen: Management technologischer Kompetenz in Innovationsprozessen, Gabler Verlag, Wiesbaden 2000, s. 21-38.

4 E. Urbanowska-Sojkin, Informacyjne fundamenty kreatywności w kontekście zarządzania strategicznego w przedsiębiorstwach, „Przegląd Organizacji” 2018, nr 3, s. 35-40.

5 E. Urbanowska-Sojkin, Imperatyw inteligencji wobec zmian w otoczeniu, „Studia i Prace Kolegium Zarządzania i Finansów SGH” 2016, z. 149, s. 61-75. 
myśleniem, wiedzą oraz ich wykorzystaniem. Twórcze wykorzystanie informacji i wiedzy (czyli inteligencja) warunkuje kreatywność organizacji.

Przejawem nonszalancji jest nie tylko brak jednoznacznego ujmowania inteligencji (zarówno tej jednostkowej, zespołowej, jak i kolektywnej, ograniczanej do przedsiębiorstwa), ale również wskazywanie na różne desygnaty dotyczące tego samego pojęcia oraz jego derywatów. W przykładowych definicjach inteligencja jest bardzo różnorodnie interpretowana przez badaczy: jako proces informacyjny, bardzo szybko rozwijający się nurt badań i aplikacji dzięki upowszechnieniu komputerów, internetu, Web 2.0 (H. Muller-Merbach), jako kapitał do informacyjnego przetwarzania (A. Scheuus), jako potencjał informacji do wykorzystania wobec przedmiotowego zaniechania (Th. Wilewsky), jako proces (M. Matsuda), ale także jego rezultat - produkt $\mathrm{w}$ formie wiedzy, motywacji i inicjatyw ${ }^{6}$. W literaturze wskazuje się na dwa określenia: inteligencję kolektywną oraz inteligencję zbiorową, które nadal wywołują dyskusję badaczy zarządzania, mającą na celu ustalenie, czy są izomorficzne. Asymetria poglądów wskazujących na zasadność rozróżniania tych pojęć jest znaczna. Ujmując owe poglądy jedynie dychotomicznie, stwierdza się, że część badaczy traktuje pojęcia jako tożsame, stosując je zamiennie, a część zdecydowanie je odróżnia. Wśród zwolenników rozróżniania pojęć są promotorzy fenomenu inteligencji zbiorowej, nieuniknionego efektu rozwoju technologii. Współczesna definicja inteligencji zbiorowej nawiązuje wprost do skutków wykorzystania postępu technologicznego7. Dotyczy zbiorowego rozwiązywania problemów (w tym decyzyjnych na różnych szczeblach zarządzania) poprzez współpracę różnych podmiotów z wykorzystaniem ICT ${ }^{8}$. Dla podkreślenia idei, zasad i metod inteligencji zbiorowej często stosowane są także inne określenia wykorzystujące porównanie do „inteligencji roju” (niem. Schwarmintelligenz), „mądrości mas” (niem. Weisheit der Massen) czy rozwiązywania problemów przez „tłum” (crowdsourcing) ${ }^{9}$. Porównanie zakresu przedmiotowego obu opisywanych określeń wskazuje na zwyczajowe

$6 \quad$ A. Jacobsen, Intelligenz von Unternehmen..., s. 21-23.

7 A. Tavakoli, D. Schlagwein, D. Schoder, Open Strategy: Literature Review, Re-Analysis of Cases and Conceptualisation as a Practice, „The Journal of Strategic Information Systems” 2017, no. 26, s. 163-184, https://doi.org/10.1016/j.jsis.2017.01.003; S. Haefliger, Orientations of Open Strategy: From Resistance to Transformation, [w:] D. Seidl, G. von Krogh, R. Whittington (red.), Cambridge Handbook of Open Strategy, Cambridge University Press, Cambridge 2018, s. 151-166, https://doi.org/10.1017/9781108347921.010; L. Dobusch, L. Dobusch, G. Müller-Seitz, Closing for the Benefit of Openness? The case of Wikimedia's open strategy process, „Organization Studies” 2019, vol. 40, issue 3, s. 343-370, https://doi.org/10.1177 /0170840617736930

$8 \quad$ M.S. Unger, Kollektive Intelligenz: Entstehung, Relevanz und Nutzungsmöglichkeiten in Wirtschaftsunternehmen, Igel Verlag RKS, Hamburg 2014.

9 E. Sixt, Schwarmökonomie und Crowdfunding: webbasierte Finanzierungssysteme im Rahmen realwirtschaftlicher Bedingungen, Gabler Verlag, Wiesbaden 2014, s. 23-35. 
odnoszenie inteligencji kolektywnej do korzyści powstających ze współpracy w grupie, w zespołach, głównie składających się z podmiotów wewnętrznych, a inteligencji zbiorowej do korzyści powstających ze współpracy jednostek, zespołów, grup społecznych połączonych siecią komputerową, działających także wirtualnie ${ }^{10}$. Takie rozumienie inteligencji kolektywnej jest niewystarczające. W definicjach inteligencji kolektywnej zabrakło, koniecznego współcześnie, dopełnienia podmiotowego i przedmiotowego wobec warunków, w których przedsiębiorstwa prowadzą działalność, implikujących rolę relacji i współpracy. Redukowanie kolektywu do podmiotów jednej organizacji, zawłaszcza podmiotów współkreujących innowacje, w wielu dziedzinach ma znaczenie fundamentalne. Chodzi o wykorzystanie twórczych procesów umysłu osób działających indywidualnie i tworzących różne zespoły przedsiębiorstwa oraz podmiotów z jego otoczenia. Potencjał kreatywności tkwi bowiem w kolektywnym poszukiwaniu rozwiązania problemów. Bezsprzeczne jest to, że inteligentne kolektywy - poprzez otwarte dyskutowanie problemów poznawczych - efektywnie pobudzają wyobraźnię i skutecznie reagują na nowe problemy i zachowania konkurentów ${ }^{11}$. Oczekiwanym efektem kolektywnej inteligencji jest zorganizowana kreatywność, której antecedencją jest otwartość podmiotów uczestniczących w dyskusjach, wzajemne zaufanie i ciekawość nowych rozwiązań. Kreatywność (ludzi, kolektywów przedsiębiorstw i innych organizacji) jest traktowana jako zasób tych podmiotów na przyszłość, a równocześnie zasób przyszłości, wobec rosnącego od lat znaczenia zasobów niematerialnych przedsiębiorstwa ${ }^{12}$.

Według Lautenschlagera współczesna kreatywność przedsiębiorstwa jest zdolnością do elastycznego odreagowywania nowych rodzajów wyzwań z otoczenia, postrzegania zmian jako szans na ich wykorzystanie i spontanicznego wprowadzania nowych rozwiązań ${ }^{13}$. Jest ona częścią kapitału niematerialnego, który równoważy najważniejsze aktywa przedsiębiorstwa ${ }^{14}$. Zarówno indywidualna, jak i kolektywna kreatywność wymaga klimatu i przestrzeni do samourzeczywistniania się, a równocześnie nie może szkodzić społecznie przez nieposzanowanie instytucji (reguł, norm, kultury). Cenny jest skutek owej kolektywnej inteligencji i kreatywności, jakim jest wzrost konkurencyjności ${ }^{15}$, szczególnie wobec krytycznych

10 T.W. Malone, M. Bernstein, Handbook of Collective Intelligence, MIT, Cambridge 2015.

11 M. Levy, Computer assisted Language Learning. Context and Conceptualization, Oxford University Press, Oxford 1997, za M.S. Unger, Kollektive Intelligenz...

12 L. Suwala, Kreativität, Kultur, Raum: Ein wirtschaftsgeographischen Beitrag am Beispiel des kulturelles Kreativitätsprozesses, Springer Verlag, Berlin 2014.

13 R.M. Holm-Hadulla, Kreativität, Springer Verlag, Heidelberg 2013.

14 M. Lautenschlager, Die Kreativität des Unternehmers, [w:] R.M. Holm-Hadulla, Kreativität, Springer Verlag, Heidelberg 2013, s. 59-76.

15 T. Seger, Kreativitätsförderung im Unternehmen, [w:] R.M. Holm-Hadulla, Kreativität, Springer Verlag, Heidelberg 2013, s. 77-108. 
uwag na temat kreatywności powodowanej jedynie przez zasoby materialne przedsiębiorstwa i bacząc na elementy duchowości inspirującej ową kreatywność oraz poważającej kontekst otoczenia ${ }^{16}$. Tym większego znaczenia nabiera społeczny, kolektywny dyskurs dotyczący podejmowanych działań, zważywszy na jego skutki ekonomiczne i społeczne dla przedsiębiorstwa i innych podmiotów w otoczeniu. Kreatywne przedsiębiorstwa uczestniczą w procesie uczenia, który następuje w dialektycznej relacji z podmiotami i zdarzeniami. W rzeczywistości oznacza to, że kreatywność nie zawsze jest efektem działania jedynie menedżerów przedsiębiorstwa, ale też podmiotów, z którymi wchodzi w relacje. Obszarami owej kreatywności przedsiębiorstwa są procesy i produkty tworzące wartość dla klienta oraz potrzeby klientów i innych interesariuszy, a także rozwiązania organizacyjne. Wsparciem dla przedmiotowych wyborów decydentów i ich wdrażania oraz realizacji jest kolektywna inteligencja.

\section{Obszary aplikacji kolektywnej inteligencji w zarządzaniu strategicznym}

Dalsza część opracowania dotyczy kolektywnej inteligencji, jej znaczenia w zarządzaniu strategicznym, a w szczególności w procesie formułowania i wdrażania strategii. Procesy te są podstawą skuteczności i efektywności działalności przedsiębiorstwa, a także jego przyszłości. W rezultacie powstają i są realizowane strategie i działania operacyjne, pozostające pod nieustannym wpływem złożonych i dynamicznych warunków w otoczeniu i przedsiębiorstwie. Kolektywną inteligencję, na którą składają się wiedza, umiejętności jej pozyskiwania, przetwarzania i wykorzystywania, tworzą podmioty (osoby, zespoły, grupy) zainteresowane sposobami oraz efektami działalności przedsiębiorstwa i z oczekiwaniami wobec tego przedsiębiorstwa. Są nimi podmioty wewnętrzne i z pola organizacyjnego. $\mathrm{W}$ teorii interesariuszy rola poszczególnych podmiotów jest ograniczona do spełnienia przez przedsiębiorstwo oczekiwań i ich skutków. Badania dowodzą znaczenia relacji z interesariuszami także z innego powodu. Jest nim potencjał zorganizowanej kreatywności i źródło kolektywnej inteligencji, nie zawsze uświadamianej, a efektem ich współpracy są kreatywne pomysły, idee, projekty, działania, systemy i struktury w przedsiębiorstwie. Wśród funkcji kolektywnej inteligencji wyróżniono uczenie się, rozpoznanie i prognozowanie warunków w otoczeniu, określanie sposobów działania i reguł ich modyfikacji pod wpływem zmian. Na rangę takiego

16 T. Petersen, Kreativitätsförderung im Unternehmen, [w:] R.M. Holm-Hadulla, Kreativität, Springer Verlag, Heidelberg 2013, s. 109-127. 
sposobu traktowania inteligencji wskazują badania w nurcie opisującym czynniki sukcesu w perspektywie strategicznej, do których zaliczono także inteligencję przedsiębiorstwa i inteligencję kolektywną ${ }^{17}$.

Współtworzenie strategii i jej wdrażanie to procesy, co oznacza, że są zmienne w czasie, ale relacje między podmiotami mogą kształtować się dynamicznie. Jedne znikają, inne się pojawiają, obserwowany jest mechanizm „wypychania” starych i wprowadzania nowych sposobów działania, sprawdzany w zmiennej rzeczywistości ${ }^{18}$. Ponadto relacje sprzężenia zwrotnego są argumentem za postrzeganiem procesualności współtworzenia strategii, jej dostosowywania do warunków działania. Nie bez znaczenia jest akceptowanie niepewności - w węższym zakresie ryzyka związanego z kolektywem, w szerszym w kontekście warunków działania i ich deskryptorów. W konsekwencji wymagane jest akceptowanie potencjalnego oportunizmu innych podmiotów. W literaturze traktującej o akceptacji niepewności wskazuje się na procesy zawieszenia, pozwalające na działanie w sytuacjach, gdy brakuje wiedzy o podmiocie, jego celach, oczekiwaniach. Przybierają one postać fikcji lub brania w nawias (aktorzy społeczni decydują się zignorować kwestie problematyczne) albo wiary ${ }^{19}$.

Nie do przecenienia jest dzielenie się wiedzą, doświadczeniem (learning by doing), artykułowanie oczekiwań. Wsparciem mogą być kultury narodowe - szczególnie w krajach o wysokim uogólnionym zaufaniu (element kapitału społecznego, otwartość na partnerów). Nie bez znaczenia dla wykorzystania inteligencji kolektywnej (kreatywności zorganizowanej) są instytucje formalne, sprzyjające ograniczaniu ryzyka współtworzenia poprzez wzmacnianie roli norm prawnych oraz porządku społecznego i gwarancję wiarygodności. Wsparciem mogą być mechanizmy kontekstowe (niepewność w otoczeniu), napędzające chęć współtworzenia wariantów rozwiązania problemów w zarządzaniu przedsiębiorstwami oraz mechanizmy konstruowane z zamiarem sprzyjania wykorzystywaniu inteligencji kolektywnej, czyli przykładowo umowy, wejścia w strukturę własnościową przedsiębiorstwa, inwestowanie w dedykowane zasoby (bazy danych, wspólne badania) i negocjacje $\mathrm{e}^{20}$.

17 H. Muller-Merbach, Die Intelligenz der Unternehmung als kritischer Wettbewerbsfaktor, [w:] M. Schwaninger (red.), Intelligente Organisationen - Konzepte für turbulente Zeiten auf Grundlage von Systemtheorie und Kybernetik, Proceedings of the Wissenschaftliche Jahrestagung der Gesellschaft für Wirtschafts- und Sozialkybernetik, Sankt Gallen - Berlin 1999, s. 79-102.

18 R.B. Dilts, Next Generation Collaboration: Befreie die kreative Kraft kollektiver Intelligenz, Castle Mount Media GmbH \& Co. KG., Erlangen 2018, s. 364.

19 G. Mollering, Vertrauen in der Krise: Worauf kann man sich im revolutionären Wandel verlassen, Gastvorlesung Max Planck Institut für Gesellschaftsforschungs, Zürich 2007, s. 111.

20 E. Urbanowska-Sojkin, Wybory strategiczne w przedsiębiorstwach z perspektywy teorii strukturacji, „Studia Oeconomica Posnaniensia” 2017, vol. 5, no. 9, s. 157-173, https://doi.org/10 .18559/SOEP.2017.9.10; E. Urbanowska-Sojkin, Instytucjonalneiorganizacyjne uwarunkowania 


\section{Systematyczne badania literatury w zakresie otwartego formutowania strategii z wykorzystaniem kolektywnej inteligencji}

W celu ustalenia aktualnego stanu wiedzy na temat otwartego formułowania strategii, w którym wykorzystuje się inteligencję i kreatywność kolektywną w rozumieniu przyjętym w opracowaniu, zastosowano metodę systematycznego przeglądu literatury, zachowując rygor metodologiczny i określone reguły ${ }^{21}$. W dalszej części rozdziału przywołano wybrane pozycje literatury, ulegając wskazaniom wynikającym z celu, a dotyczącym pojęć związanych z otwartym formułowaniem strategii oraz praktyki jego wykorzystania.

Inspirujący przykład badań dotyczących otwartego formułowania strategii został zawarty w opracowaniu przygotowanym przez zespół zagranicznych naukowców - Tavakoliego, Schlagweina i Schodera ${ }^{22}$, którzy przeanalizowali ponad 6000 publikacji (wykorzystując wyszukiwania oparte na słowach kluczowych, które doprowadziły do ogromnej liczby „trafien” w bazach naukowych). Jedynie 99 publikacji dotyczyło otwartości strategii i te ostatecznie badacze uznali za odpowiednie. Efektem analiz autorów jest zaproponowany program badawczy na bazie udokumentowanych przypadków zastosowania otwartej strategii w praktyce przedsiębiorstw (m.in. Daimler, IBM, Premium Cola, Red Hat, Wikimedia Foundation).

Sailer, Schlagwein i Schoder ${ }^{23}$ są autorami opracowania zawierającego rezultaty badania otwartego formułowania strategii. Zawiera ono współczesną wiedzę na temat otwartej strategii, w szczególności konieczne do spełnienia warunki zastosowania otwartego formułowania strategii, opis procesu otwartego formułowania strategii oraz konsekwencje owej otwartości dla przedsiębiorstw. Wsparciem dla autorskich ustaleń były 64 artykuły, a także 52 studia przypadku. W kontekście zapewnień autorów te liczby świadczą o relatywnie niskim poziomie intensywności

wyborów strategicznych w przedsiębiorstwach, „Prace Naukowe Uniwersytetu Ekonomicznego we Wroctawiu" 2018, nr 538, s. 432-443, https://doi.org/10.15611/pn.2018.538.35

21 Pozwala to w sposób obiektywny dokonać przeglądu, a zarazem zarysować i ocenić istniejący dorobek naukowy, będący podsumowaniem dotychczasowych publikacji. Użyteczność przeglądu polega między innymi na możliwości ustalenia luk poznawczych, syntetyzacji wyników uzyskanych przez innych autorów oraz zaproponowaniu nowych kierunków badań - W. Czakon, Metodyka systematycznego przeglqdu literatury, [w:] W. Czakon (red.), Podstawy metodologii badań w naukach o zarzq̨dzaniu, Oficyna a Wolters Kluwer business, Warszawa 2013, s. 47-67.

22 A. Tavakoli, D. Schlagwein, D. Schoder, Open Strategy: Literature Review...

23 A.-S. Sailer, D. Schlagwein, D. Schoder, Open Strategy: State of the Art Review and Research Agenda, Thirty Eighth International Conference on Information Systems, South Korea 2017. 
(popularności) opisu naukowego. Zaletą dokonanych analiz jest zwrócenie uwagi na rolę IT oraz zidentyfikowanie nieodkrytych dotąd obszarów w ramach badań nad otwartą strategią, dotyczących konsekwencji otwartości strategicznej przedsiębiorstwa.

Otwartość strategiczna, a szczególnie otwarte formułowanie strategii, to problematyka, która interesuje badaczy zajmujących się profesjonalnie systemami IT i poszukujących najlepszego sposobu ich użycia, także poprzez wykorzystanie ich potencjału do wspomagania procesów decyzyjnych. Poszukiwanie użyteczności systemów IT stało się praprzyczyną formułowania zbiorowej inteligencji, o czym była już mowa, i wiązało się z fundamentalną rolą ICT w realizacji otwartej strategii. Opis tego typu badań sporządzili Morton i Amrollahi24, wskazując praktyczne sposoby realizowania otwartości strategicznej, stosowane przez zarządzających w rozpoznawalnych na świecie organizacjach (m.in. EU, NATO, Griffith University, Oxfam, UK Public Research University, Xamin Open Source Project). Badania nie wykazały replikacji procesów otwartego formułowania strategii, mają one formuły zindywidualizowane.

W opracowaniu autorstwa Sunnera i Atesa ${ }^{25}$ sformułowano kluczowe zasady otwartej strategii, przestrzegane przez praktyków. Wykorzystano do tego celu analizę 53 artykułów (wyselekcjonowanych według kryteriów słów kluczowych). Są nimi: włączenie do procesu formułowania strategii, czynna partycypacja w tworzeniu elementów opcji strategicznych i w ich wycenie, transparentność procesu, a także wspomaganie przez IT oraz dostępność do systemów IT - platform współpracy i dyskusji.

W krajowym piśmiennictwie naukowym koncepcja Open Strategy jest podejmowana okazjonalnie i ma charakter fragmentarycznych opracowań ${ }^{26}$. Wykorzystanie rezultatów metody systematycznego przeglądu literatury światowej pozwala zauważyć, że dotychczasowe badania w zakresie otwartej strategii koncentrują się wśród badaczy skupionych wokół dwóch międzynarodowych sieci społecznościowych - Open Strategy Network oraz Strategy as Practice International Network. Analiza ich zawartości ukazuje, że opracowania skierowane są zarówno do odbiorców akademickich, w głównej mierze amerykańskich, australijskich

24 J. Morton, A. Amrollahi, Open Strategy Intermediaries? A Framework for Understanding the Role of Facilitators in Open Strategy-Making, Proceedings of the Twenty-Sixth European Conference on Information Systems (ECIS), Twenty-Sixth European Conference on Information Systems (ECIS), Portsmouth, 23-28 June 2018.

25 A. Sunner, A. Ates, Open strategy: a review and research agenda, BAM 2019 Conference Proceedings, British Academy of Management, London 2019.

26 A. Kozarkiewicz, Between it and Societal Shift: Preconditions of Open Strategizing, „Management Sciences. Nauki o Zarządzaniu" 2018, t. 23, nr 4, s. 3-8. 
i europejskich, jak i do praktyków gospodarczych przywoływanych w licznych studiach przypadku ${ }^{27}$.

Pomimo powstających prac podkreśla się, że dokonane do tej pory przeglądy literatury zawierają pewne ograniczenia, między innymi brak wskazania konsensualnej definicji otwartej strategii, zbyt liczne pojęcia stanowiące fundamenty koncepcji oraz brak wyraźnych analiz empirycznych w tym zakresie, co stanowi istotne przesłanki do prowadzenia kolejnych badań literaturowych. Posługując się określeniem Czakona ${ }^{28}$, odnoszącego się do wiedzy o sieciach gospodarczych, są to jedynie „okruchy wiedzy" dotyczące otwartego formułowania strategii i jej implementacji.

\section{Otwartość strategiczna i ramy otwartej strategii}

Otwartość strategiczna, której urzeczywistnieniem jest otwarta strategia, określana jest jako nowy paradygmat zarządzania strategicznego 29 , będący zbiorem poglądów dotyczących zwiększenia w procesie formułowania strategii roli pomysłów na strategię spoza zespołu strategów (wyższych i niższych szczebli) oraz zapewnienia interesariuszom (konsultantom, klientom, dostawcom, a nawet konkurentom) dostępu do wkładu, procesu i wyników strategii, co dowodzi uczestnictwa osób spoza granic organizacyjnych ${ }^{30}$.

W literaturze przedmiotu wskazuje się, że formułowanie otwartej strategii buduje relacje $\mathrm{z}$ interesariuszami i poprawia zaangażowanie podmiotów wewnętrznych i zewnętrznych w proces decyzyjny ${ }^{31}$, w tym osób postronnych ${ }^{32}$. Założenia budowania otwartej strategii wykraczają zatem poza kierownictwo wyższego szczebla i jego bezpośrednich doradców ${ }^{33}$. Zagraniczne opracowania zawierają

27 A. Weinert, Otwartość strategiczna przedsiębiorstw a systemy IT wspomagajqce zarzqdzanie, „Studia i Prace Kolegium Zarzadzania i Finansów SGH” 2019, z. 175, s. 213-228.

28 Czakon W., Okruchy wiedzy. Niejednoznaczność przyczynowa w badaniach sieci gospodarczych, „Zeszyty Naukowe Wyższej Szkoły Bankowej w Poznaniu” 2015, t. 64, nr 7, s. 19.

29 A. Amrollahi, B. Rowlands, OSPM: A Design Methodology for Open Strategic Planning, Twenty-second Americas Conference on Information Systems, San Diego 2016.

30 R. Whittington, L. Cailluet, B. Yakis-Douglas, Opening Strategy: Evolution of a Precarious Profession, „British Journal of Management” 2011, vol. 22(3), s. 535.

31 S. Clegg, M. van Rijmenam, J. Schweitzer, The Politics of Openness, [w:] D. Seidl, G. von Krogh, R. Whittington (red.), Cambridge Handbook of Open Strategy, Cambridge University Press, Cambridge 2018, s. 314, https://doi.org/10.1017/9781108347921.019

32 J. Birkinshaw, Reflections on open strategy, „Long Range Planning” 2017, vol. 50(3), s. 423, https://doi.org/10.1016/j.lrp.2016.11.004

33 D. Seidl, G. von Krogh, R. Whittington, Defining Open Strategy: Dimensions, Practices, Impacts, and Perspectives, [w:] D. Seidl, G. von Krogh, R. Whittington (red.), Cambridge Handbook of Open Strategy, Cambridge University Press, Cambridge 2018, s. 16, https://doi.org /10.1017/9781108347921.002 
liczne definicje pojęcia otwarta strategia ${ }^{34}$. Ich analiza pozwala określić ramy otwartego formułowania strategii w przedsiębiorstwie. Do opisu otwartego formułowania strategii autorzy wykorzystują różnego rodzaju cechy, traktowane jako ich desygnaty przybliżające istotę procesu i jego skutku, czyli strategii powstałej przez współtworzenie $z$ udziałem różnych podmiotów z pola organizacyjnego ${ }^{35}$.

Otwarta strategia (jako koncepcja i działania) jest zakorzeniona w wielu wcześniejszych propozycjach dotyczących wyboru i implementacji strategii ${ }^{36}$. Stwarza zatem możliwości powrotu do selektywnie wybranych elementów formułowania i implementacji strategii, poddanych modyfikacji z zamiarem wykorzystania sprawdzonych sposobów w nowych warunkach działania przedsiębiorstwa. Oznacza więc zerwanie z założeniem, że najwyższe kierownictwo kontroluje proces i treść tworzenia strategii, poprzez zburzenie koncepcyjne granic firmy po spostrzė̇eniach wyciągniętych z badań nad innowacjami ${ }^{37}$.

Ostatnie inicjatywy badawcze w zakresie otwartej strategii stanowią wyraźny krok w kierunku czynników „napędzających” i determinujących proces formułowania oraz ostatecznie wybory strategiczne. Birkinshaw ${ }^{38}$ sugeruje, że tzw. zbiorowy zmysł (innym razem traktowany jako kolektywna inteligencja i zorganizowana kreatywność) na rynkach kapitałowych jest ważnym wymiarem otwartego formułowania i wdrażania strategii prywatnych firm. Umieszcza ten wymiar na pierwszym miejscu w ramach cech opisujących oba pojęcia. Równocześnie wskazuje na komplementarność zaawansowanych ICT względem otwartego formułowania i wdrażania strategii (otwartej strategii). Uwaga badaczy i praktyków skupiona jest przede wszystkim na mediach społecznościowych - głównie ze względu na upodmiotowienie klientów i ich znaczenie dla współtworzenia wartości, ale także upodmiotowienie aktorów społecznych w ogóle i ich rolę we współtworzeniu sposobów działania przedsiębiorstw (rozwój zrównoważony, efektywność społeczna). Technologie informacyjne i komunikacyjne są radykalnymi bodźcami do zwiększonej otwartości strategicznej, w tym formułowania i implementacji strategii ${ }^{39}$. Nowoczesne technologie umożliwiają nie tylko szersze, bardziej kompleksowe i terminowe przekazywanie strategicznie istotnych informacji, ale także włączenie do strategicznych rozmów większej grupy odbiorców w bardziej

34 A. Sunner, A. Ates, Open strategy..., s. 12.

35 L. Dobusch, L. Dobusch, G. Müller-Seitz, Closing for the Benefit of Openness...

36 A. Tavakoli, D. Schlagwein, D. Schoder, Open Strategy: Literature Review..., s. 178.

37 S. Haefliger, Orientations of Open Strategy..., s. 151.

38 J. Birkinshaw, Reflections...

39 J. Baptista i wsp., Social Media and the Emergence of Reflexiveness as a New Capability for Open Strategy, „Long Range Planning” 2017, vol. 50(3), s. 322-336, https://doi.org/10.1016 /j.Irp.2016.07.005 
efektywny i zaawansowany sposób. Jednocześnie pojawiły się nowe, inne niż technologiczne czynniki zwiększające otwartość strategiczną, jak na przykład presja społeczna ze strony działaczy konsumenckich i akcjonariuszy, rosnący opór kulturowy wobec hierarchicznych form kontroli oraz powszechne znoszenie granic organizacyjnych ${ }^{40}$.

Spełnienie oczekiwań dotyczących sformułowania strategii dostosowywanych do otoczenia jest rezultatem kolektywnej kreatywności, warunkowanej:

- infrastrukturą IT, narzędziami i oprogramowaniem, platformami internetowymi ${ }^{41}$;

- kompetencjami osób uczestniczących we współtworzeniu i modyfikacji dostosowawczej oraz wdrożeniu strategii ${ }^{42}$;

- orientacją i motywacją oraz gotowością osób uczestniczących w tych procesach, zorientowanych na tworzenie wartości ważnych dla podmiotów, które reprezentują, i dla wszystkich uczestników procesu tworzenia wartości wspólnej ${ }^{43}$;

- zaufaniem do uczestników otwartego procesu formułowania (modyfikowania) i wdrażania strategii ${ }^{44}$;

- instytucjonalnymi, kulturowymi, organizacyjnymi warunkami współpracy międzynarodowej w sferze projektowania i wdrażania strategii w optyce realizacji ich celów oraz celów wspólnych ${ }^{45}$.

\section{Wstępne wyniki badań w przedsiębiorstwach 46}

W związku z dynamicznymi zmianami w otoczeniu przedsiębiorstw, potrzebą modyfikacji strategii oraz wzajemnymi powiązaniami międzyorganizacyjnymi uwagę badaczy skupiła koncepcja otwartej strategii, wsparta na kolektywnym

40 R. Whittington, Opening Strategy. Professional Strategists and Practice Change, 1960 to Today, Oxford University Press, Oxford 2019.

41 A. Tavakoli, D. Schlagwein, D. Schoder, Open Strategy: Consolidated Definition and Processual Conceptualization, International Conference for Information Systems (ICIS), Fort Worth 2015; J. Baptista i wsp., Social Media...

42 A. Kozarkiewicz, Between it and Societal Shift...

43 M.M. Appleyard, H.W. Chesbrough, The Dynamics of Open Strategy: From Adoption to Reversion, „Long Range Planning” 2017, vol. 50(3), s. 310-321; S. Haefliger, Orientations of Open Strategy...

44 J. Birkinshaw, Reflections...; S. Clegg, M. van Rijmenam, J. Schweitzer, The Politics...

45 A. Tavakoli, D. Schlagwein, D. Schoder, Open Strategy: Consolidated Definition...; L. Dobusch, L. Dobusch, G. Müller-Seitz, Closing for the Benefit of Openness...

46 Źródłem oceny są wyniki empiryczne z badania przeprowadzonego we wrześniu 2019 roku w ramach zadań naukowych realizowanych w Katedrze Zarządzania Strategicznego Uniwersytetu Ekonomicznego w Poznaniu. Badanie jest pierwszą częścią szerszego projektu 
współtworzeniu - związana z formułowaniem strategii i jej modyfikowaniem (jako skutkiem zmian w otoczeniu i orientacji na dostosowywanie) oraz jej wdrażaniem. Podstawowym celem badania jest identyfikacja uczestników procesów strategicznych w przedsiębiorstwach oraz określenie czy zaangażowanie tych osób w proces decyzyjny świadczy o otwartości strategicznej przedsiębiorstwa z wykorzystaniem potencjału kolektywnej inteligencji ${ }^{47}$.

W ramach przeprowadzonych badań podjęto próbę sprawdzenia znajomości otwartej strategii wspartej na kolektywnym współtworzeniu ${ }^{48}$. Zdecydowana większość badanych (63\%) nie zadeklarowała znajomości podstawowych założeń koncepcji otwartej strategii, w tym aż dla 51\% strategów były one „zdecydowanie nieznane”. Jedynie 18\% respondentów uważało, że założenia te są im „w pewnym zakresie znane”. Niepokoi brak wśród uczestników badania osób świadomych cech otwartego formułowania strategii i jej implementacji.

Struktura wypowiedzi osób uczestniczących w procesie formułowania i implementacji strategii świadczy o stosunkowo słabym rozpoznaniu nowej koncepcji zarządzania strategicznego wśród praktyków w Polsce, co wydaje się w pełni zrozumiałe w kontekście rozpowszechnienia koncepcji głównie w krajach zachodnich oraz fragmentarycznych, doraźnych, przedmiotowych obserwacji literaturowych w krajowym piśmiennictwie naukowym, wykazującym na nieliczne artykuły opisujące i wyjaśniające koncepcję otwartej strategii ${ }^{49}$. Należy uwzględnić także szerszy kontekst zidentyfikowanego niskiego poziomu wiedzy (a właściwie jej braku) na temat otwartego formułowania strategii. Obejmuje on uwarunkowania działalności przedsiębiorstw, w szczególności wewnętrzne, wyrażone w cechach systemu

badawczego pt. „Open Strategy w Polsce”. Dane jakościowe o charakterze ilościowym zebrano od respondentów anonimowo i dobrowolnie. Kwestionariusz ankiety elektronicznej możliwy był do wypetnienia wyłącznie jednorazowo on-line (opublikowany na stronie https://strategicznie.pl/). Badanie zostało oparte na gromadzeniu danych w sposób zamknięty. W badaniu zastosowano system zarządzania ankietami LimeSurvey (na zasadach open-source). Jako operat losowania wykorzystano bazę danych EMIS Professional, za pomocą której uzyskano dostęp do wykazu jednostek (populacji badanej), zawierającego aktualne dane kontaktowe (np. adres e-mail). Za pomocą poczty elektronicznej rozestano zaproszenia do udziału w badaniu. Badanie w momencie przygotowywania niniejszego opracowania nadal trwa ze względu na zobowiązania wynikające z projektu badań.

47 Badanie skierowane zostało do właścicieli firm, członków zarządów, dyrektorów generalnych, dyrektorów wykonawczych, dyrektorów strategicznych i zarządzających oraz praktyków strategii.

48 Do tej pory otrzymano łącznie 51 wypełnionych ankiet (kompletnych) od przedsiębiorstw prowadzących dziatalność na terenie Polski. Populację badanych przedsiębiorstw stanowity podmioty zatrudniające powyżej 49 osób, o różnym profilu działalności, pochodzeniu kapitału oraz długości działania.

49 A. Weinert, Otwartość strategiczna... 
zarządzania (stylu, metodach i technikach zarządzania) oraz kulturze organizacyjnej, a także uwarunkowania zewnętrzne. Wśród uwarunkowań z otoczenia nie bez znaczenia są praktyki międzyorganizacyjne, sektorowe. Wielokrotnie we wcześniejszych badaniach prowadzonych w przedsiębiorstwach, dotyczących wyborów strategicznych, identyfikowano powszechność podejścia planistycznego i pozycyjnego do formułowania i wyborów strategii ${ }^{50}$.

Elementem warunkującym wybory jest powszechnie zaakceptowane i stosowane podejście preskryptywne, dalekie od partycypacji w procesie formułowania strategii podmiotów (aktorów) z wnętrza oraz jego otoczenia. Zakres wykorzystania potencjału tkwiącego w otwartym formułowaniu strategii (kolektywnej inteligencji) charakteryzuje się równie niskim co poziom wiedzy poziomem aplikacji w praktyce. Badani relatywnie rzadko akceptowali angażowanie zewnętrznych odbiorców w proces tworzenia strategii przedsiębiorstwa (partycypacja) $(17,6 \%)$ oraz zewnętrzne konsultacje dotyczące strategii (włączanie) (23,5\%), a także przejrzystość relacji (29,4\%). Najwyższą akceptację odnotowano dla demokratycznego podejmowania decyzji strategicznych (39,2\%). Takie podejście wymaga dużej dojrzałości decydentów w zakresie społecznej odpowiedzialności i nie dotyczy z pewnością wszystkich decyzji strategicznych. Może to świadczyć o uwzględnianiu opinii interesariuszy wewnętrznych przedsiębiorstwa.

Deklaratywnym sformułowaniom przeciwstawiono opinie o praktyce menedżerów strategicznych przedsiębiorstw. Zdecydowana większość respondentów $(62,7 \%)$ stwierdziła, że w procesie formułowania strategii uczestniczą stratedzy przedsiębiorstwa, co jest związane z jednoznacznym brakiem partycypacji innych osób na poziomie strategicznym. Część przedsiębiorstw angażowała pracowników niższych szczebli (39,2\%). Wynik ten wart jest odnotowania przede wszystkim dlatego, że pokazuje otwartość podmiotów na partycypację swoich pracowników i ich udział w dyskusjach i tworzeniu rozwiązań problemów strategicznych wewnątrz przedsiębiorstwa. Mniej niż jedna trzecia badanych korzystała z konsultacji zewnętrznych $(29,4 \%)$. Niewielki odsetek menedżerów strategicznych $(3,9 \%)$ uważał, że ich przedsiębiorstwo dostrzega znaczenie kolektywnej inteligencji i zasadność jej wykorzystania w procesie formułowania strategii we współpracy z organizacjami non-profit.

50 Między innymi: E. Urbanowska-Sojkin (red.), Podstawy wyborów strategicznych w przedsiębiorstwach, Polskie Wydawnictwo Ekonomiczne, Warszawa 2011; A. Kaleta (red.), Ewolucja zarządzania strategicznego w trakcie rozwoju przedsiębiorstwa, Wydawnictwo C.H. Beck, Warszawa 2014; A. Sopińska, Orientacja strategiczna przedsiębiorstw z sektora MSP w świetle badań, „Organizacja i Kierowanie” 2014, nr 1A, s. 217-228; M. Romanowska, Myślenie strategiczne - myślenie przedsiębiorcze. Obserwacje postaw i zachowań strategicznych menedżerów w kryzysie, „Marketing i Rynek” 2015, nr 9, s. 553-564. 
W ramach częściowych wyników badania odnotowano również, że ponad jedna trzecia respondentów uważała poziom nastawienia w ich przedsiębiorstwie do informowania interesariuszy o decyzjach strategicznych za pomocą różnych technologii ICT za niski. Jednocześnie w badanych przedsiębiorstwach wykorzystywało się platformy blogowe, platformy crowdsourcingowe, programy do aktywnego słuchania pracowników, platformy konkursowe, ankiety elektroniczne i platformy społecznościowe, budujące poczucie wspólnoty i potrzebę współdziałania. Warto wspomnieć również, że tworzono własne metody i systemy elektroniczne do wspierania procesu formułowania strategii oraz korzystano z narzędzi partnerów specjalizujących się w tworzeniu i zmianach strategii, co jest optymistycznym „okruchem" w wynikach badania.

\section{Podsumowanie}

W literaturze coraz częściej zauważana jest potrzeba prowadzenia przejrzystego procesu formułowania i realizacji strategii przedsiębiorstwa poprzez angażowanie wewnętrznych i zewnętrznych interesariuszy. W polskiej praktyce gospodarczej koncepcja Open Strategy jest jednak jeszcze relatywnie słabo znana wśród menedżerów strategicznych. Wskazania literaturowe nie zostały w pełni odzwierciedlone w próbie badawczej. Wyniki empiryczne wskazują, że w badanych podmiotach dominuje podejście zakładające zamknięty proces formułowania strategii, skoncentrowany na udziale głównych strategów, bez uwzględniania opinii innych interesariuszy.

Pytanie, czy przedsiębiorstwa w Polsce będą się coraz bardziej otwierać na możliwości kolektywnego współtworzenia strategii, pozostaje nadal zasadne. Kolejne pytanie dotyczy skuteczności wybranych i implementowanych decyzji strategicznych przedsiębiorstwa, powstałych z wykorzystaniem potencjału inteligencji kolektywu interesariuszy i zorganizowanej kreatywności. Z pewnością pytania odnoszące się do otwartości strategicznej przedsiębiorstw będą się mnożyć - także jako skutek doświadczania nowych rozwiązań. Powinny one być przedmiotem eksploracji, której skutków nie sposób z perspektywy 2020 roku przewidzieć. Pewne jest, że wobec zmian w otoczeniu i samych podmiotów gospodarczych zainteresowanie badaczy i praktyków w tym zakresie niezmiennie dotyczyć będzie efektów współtworzenia strategii postrzeganych w szerokim kontekście ekonomicznym i społecznym, a także metod wdrażania otwartego formułowania strategii oraz przeszkód różnego rodzaju. 
Bibliografia

Amrollahi A., Rowlands B., OSPM: A Design Methodology for Open Strategic Planning, Twenty-second Americas Conference on Information Systems, San Diego 2016.

Appleyard M.M., Chesbrough H.W., The Dynamics of Open Strategy: From Adoption to Reversion, „Long Range Planning” 2017, vol. 50(3), s. 310-321.

Baptista J., Wilson A.D., Galliers R.D., Bynghall S., Social Media and the Emergence of Reflexiveness as a New Capability for Open Strategy, „Long Range Planning” 2017, vol. 50(3), s. 322-336, https://doi.org/10.1016/j.Irp.2016.07.005

Birkinshaw J., Reflections on open strategy, „Long Range Planning” 2017, vol. 50(3), s. 423-426, https://doi.org/10.1016/j.Irp.2016.11.004

Clegg S., Rijmenam M. van, Schweitzer J., The Politics of Openness, [w:] D. Seidl, G. von Krogh, R. Whittington (red.), Cambridge Handbook of Open Strategy, Cambridge University Press, Cambridge 2018, s. 307-325, https://doi.org/10.1017/9781108347921.019

Czakon W., Metodyka systematycznego przeglqdu literatury, [w:] W. Czakon (red.), Podstawy metodologii badań w naukach o zarządzaniu, Oficyna a Wolters Kluwer business, Warszawa 2013, s. 47-67.

Czakon W., Okruchy wiedzy. Niejednoznaczność przyczynowa w badaniach sieci gospodarczych, „Zeszyty Naukowe Wyższej Szkoły Bankowej w Poznaniu” 2015, t. 64, nr 7, s. 11-22.

Dilts R.B., Next Generation Collaboration: Befreie die kreative Kraft kollektiver Intelligenz, Castle Mount Media GmbH \& Co. KG., Erlangen 2018.

Dobusch L., Dobusch L., Müller-Seitz G., Closing for the Benefit of Openness? The case of Wikimedia's open strategy process, „Organization Studies” 2019, vol. 40, issue 3, s. 343-370, https://doi .org/10.1177/0170840617736930

Haefliger S., Orientations of Open Strategy: From Resistance to Transformation, [w:] D. Seidl, G. von Krogh, R. Whittington (red.), Cambridge Handbook of Open Strategy, Cambridge University Press, Cambridge 2018, s. 151-166, https://doi.org/10.1017/9781108347921.010

Holm-Hadulla R.M., Kreativität, Springer Verlag, Heidelberg 2013.

Jacobsen A., Intelligenz von Unternehmen: Management technologischer Kompetenz in Innovationsprozessen, Gabler Verlag, Wiesbaden 2000.

Kaleta A. (red.), Ewolucja zarzq̨dzania strategicznego w trakcie rozwoju przedsiębiorstwa, Wydawnictwo C.H. Beck, Warszawa 2014.

Kozarkiewicz A., Between it and Societal Shift: Preconditions of Open Strategizing, „Management Sciences. Nauki o Zarządzaniu" 2018, t. 23, nr 4, s. 3-8.

Koźmiński A.K., Piotrowski W., Zarzq̨dzanie. Teoria i praktyka, Wydawnictwo Naukowe PWN, Warszawa 2013.

Lautenschlager M., Die Kreativität des Unternehmers, [w:] R.M. Holm-Hadulla, Kreativität, Springer Verlag, Heidelberg 2013, s. 59-76.

Levy M., Computer assisted Language Learning. Context and Conceptualization, Oxford University Press, Oxford 1997.

Malone T.W., Bernstein M., Handbook of Collective Intelligence, MIT, Cambridge 2015.

Mollering G., Vertrauen in der Krise: Worauf kann man sich im revolutionären Wandel verlassen, Gastvorlesung Max Planck Institut für Gesellschaftsforschungs, Zürich 2007.

Morton J., Amrollahi A., Open Strategy Intermediaries? A Framework for Understanding the Role of Facilitators in Open Strategy-Making, Proceedings of the Twenty-Sixth European Conference on Information Systems (ECIS), Twenty-Sixth European Conference on Information Systems (ECIS), Portsmouth, 23-28 June 2018.

Muller-Merbach H., Die Intelligenz der Unternehmung als kritischer Wettbewerbsfaktor, [w:] M. Schwaninger (red.), Intelligente Organisationen - Konzepte für turbulente Zeiten auf 
Grundlage von Systemtheorie und Kybernetik, Proceedings of the Wissenschaftliche Jahrestagung der Gesellschaft für Wirtschafts- und Sozialkybernetik, Sankt Gallen - Berlin 1999, s. 79-102.

Petersen T., Kreativitätsförderung im Unternehmen, [w:] R.M. Holm-Hadulla, Kreativität, Springer Verlag, Heidelberg 2013, s. 109-127.

Romanowska M., Myślenie strategiczne - myślenie przedsiębiorcze. Obserwacje postaw i zachowań strategicznych menedżerów w kryzysie, „Marketing i Rynek” 2015, nr 9, s. 553-564.

Sailer A.-S., Schlagwein D., Schoder D., Open Strategy: State of the Art Review and Research Agenda, Thirty Eighth International Conference on Information Systems, South Korea 2017.

Seger T., Kreativitätsförderung im Unternehmen, [w:] R.M. Holm-Hadulla, Kreativität, Springer Verlag, Heidelberg 2013, s. 77-108.

Seidl D., Krogh G. von, Whittington R., Defining Open Strategy: Dimensions, Practices, Impacts, and Perspectives, [w:] D. Seidl, G. von Krogh, R. Whittington (red.), Cambridge Handbook of Open Strategy, Cambridge University Press, Cambridge 2018, s. 9-26, https://doi.org/10 $.1017 / 9781108347921.002$

Sixt E., Schwarmökonomie und Crowdfunding: webbasierte Finanzierungssysteme im Rahmen realwirtschaftlicher Bedingungen, Gabler Verlag, Wiesbaden 2014, s. 23-35.

Sopińska A., Orientacja strategiczna przedsiębiorstw z sektora MSP w świetle badań, „Organizacja i Kierowanie" 2014, nr 1A, s. 217-228.

Sunner A., Ates A., Open strategy: a review and research agenda, BAM 2019 Conference Proceedings, British Academy of Management, London 2019.

Suwala L., Kreativität, Kultur, Raum: Ein wirtschaftsgeographischen Beitrag am Beispiel des kulturelles Kreativitätsprozesses, Springer Verlag, Berlin 2014.

Tavakoli A., Schlagwein D., Schoder D., Open Strategy: Consolidated Definition and Processual Conceptualization, International Conference for Information Systems (ICIS), Fort Worth 2015.

Tavakoli A., Schlagwein D., Schoder D., Open Strategy: Literature Review, Re-Analysis of Cases and Conceptualisation as a Practice, „The Journal of Strategic Information Systems” 2017, no. 26, s. 163-184, https://doi.org/10.1016/j.jsis.2017.01.003

Unger M.S., Kollektive Intelligenz: Entstehung, Relevanz und Nutzungsmöglichkeiten in Wirtschaftsunternehmen, Igel Verlag RKS, Hamburg 2014.

Urbanowska-Sojkin E., Imperatyw inteligencji wobec zmian w otoczeniu, „Studia i Prace Kolegium Zarządzania i Finansów SGH" 2016, z. 149, s. 61-75.

Urbanowska-Sojkin E., Informacyjne fundamenty kreatywności w kontekście zarzq̨dzania strategicznego w przedsiębiorstwach, „Przegląd Organizacji” 2018, nr 3, s. 35-40.

Urbanowska-Sojkin E., Instytucjonalne i organizacyjne uwarunkowania wyborów strategicznych w przedsiębiorstwach, „Prace Naukowe Uniwersytetu Ekonomicznego we Wrocławiu” 2018, nr 538, s. 432-443, https://doi.org/10.15611/pn.2018.538.35

Urbanowska-Sojkin E., Wybory strategiczne w przedsiębiorstwach z perspektywy teorii strukturacji, „Studia Oeconomica Posnaniensia” 2017, vol. 5, no. 9, s. 157-173, https://doi.org/10 $.18559 /$ SOEP.2017.9.10

Urbanowska-Sojkin E. (red.), Podstawy wyborów strategicznych w przedsiębiorstwach, Polskie Wydawnictwo Ekonomiczne, Warszawa 2011.

Weinert A., Otwartość strategiczna przedsiębiorstw a systemy IT wspomagajqce zarzqdzanie, „Studia i Prace Kolegium Zarzadzania i Finansów SGH" 2019, z. 175, s. 213-228.

Whittington R., Opening Strategy. Professional Strategists and Practice Change, 1960 to Today, Oxford University Press, Oxford 2019.

Whittington R., Cailluet L., Yakis-Douglas B., Opening Strategy: Evolution of a Precarious Profession, „British Journal of Management” 2011, vol. 22(3), s. 531-544. 


\section{Streszczenie}

Problematyka podjęta w opracowaniu dotyczy współczesnych wyzwań w obszarze zarządzania strategicznego, a w szczególności zagadnienia otwartości strategicznej (strategic openness), przejawiającej się między innymi w procesie formułowania strategii, powszechnie określanego jako otwarta strategia (Open Strategy). Teoretyczne fundamenty nowej koncepcji zarządzania strategicznego wskazują na znaczenie różnych czynników dla otwartego procesu strategicznego, w tym przede wszystkim kolektywnej inteligencji (collective intelligence), warunkującej wybory strategiczne, ich wdrożenie oraz skuteczność. Celem opracowania jest wskazanie znaczenia kolektywnej inteligencji, ustalenie ram koncepcyjnych otwartej strategii wspartej na kolektywnym współtworzeniu oraz przedstawienie wyników jej aplikacji w przedsiębiorstwach w warunkach polskich. Wyniki empiryczne pozwalają stwierdzić, że koncepcja otwartej strategii jest jeszcze stosunkowo słabo rozpoznana wśród respondentów, a w badanych przedsiębiorstwach dominuje podejście charakteryzujące się zamkniętym procesem formułowania strategii, skoncentrowanym na głównych strategach. Powstają zatem kolejne pytania badawcze dotyczące ustalenia przyczyn i perspektyw otwartości strategicznej przedsiębiorstw.

Słowa kluczowe: otwartość strategiczna, otwarte formułowanie strategii, kolektywna inteligencja, przedsiębiorstwo

\section{Open formulation of strategy using collective intelligence by enterprises}

\section{Abstract}

The issues discussed in the article concern contemporary challenges in the area of strategic management, and in particular the issue of strategic openness, manifested, inter alia, in the process of formulating the strategy, commonly referred to as the Open Strategy. The theoretical foundations of the new concept of strategic management point to the importance of various factors for an open process, including primarily Collective Intelligence conditioning strategic choices, their implementation and efficiency. The aim of the article is to establish a conceptual framework for an open strategy supported by collective co-creation and to present the results of applications in enterprises in Polish conditions. Preliminary empirical results show that the Open Strategy concept is still relatively poorly recognized among the respondents, and in the surveyed enterprises the approach characterized by a closed strategy formulation process focused only on the main strategies within the organization dominates. Therefore, further research questions arise about determining the causes and perspectives of an open strategy.

Keywords: strategic openness, open strategy, collective intelligence, enterprise 